\title{
Achieving Legitimacy in Entrepreneurship Education: a case study
}

\author{
Dr Miruna Radu Lefebvre \\ Associate Professor of Entrepreneurship, AUDENCIA PRES LUNAM \\ mradu@audencia.com \\ Audencia Nantes - École de Management \\ 8 route de la Jonelière - B.P. 31222 - 44312 Nantes Cedex 3 - France \\ $+33(2) 40373434$ \\ Dr Renaud Redien-Collot \\ Director of International Affairs, NOVANCIA \\ rrediencollot@novancia.f \\ NOVANCIA \\ 3 rue Armand Moisant - 75731 Paris cedex 15 - France \\ + 33 (1) 55655715
}

\begin{abstract}
This paper examines the legitimating process of a French higher education institution entirely dedicated to entrepreneurship. Management and entrepreneurship education strives both for academic and market legitimacies. We think entrepreneurship education is confronted with an additional challenge: building political legitimacy. We analyze the "extreme case" study of a French business school dedicated to entrepreneurship. We examined the business school's legitimation process over a period of six years, from 2004 to 2010. This "extreme case" may be informative for other business schools willing to reach academic, market and political legitimacies while at the same time trying to develop a coherent and stable global strategy in a competitive higher education landscape. This is the first article dealing with the topic of legitimacy acquisition processes, with the aim of emphasizing the institutionalization of entrepreneurial mindset in French entrepreneurship higher education.
\end{abstract}

\section{KEYWORDS}

Legitimacy, institutionalization, entrepreneurship education, extreme case 


\section{INTRODUCTION}

French entrepreneurship education has been increasingly gaining ground for the last ten years. Entrepreneurship higher education is well integrated into national and European policy frameworks aiming to stimulate entrepreneurial spirit and to increase the number of start-ups all over the continent. However, entrepreneurship higher education is regularly facing a major dilemma: simultaneously achieving academic, market and political legitimacies. According to Binks and his colleagues (2006), management and entrepreneurship education have to demonstrate both academic and market legitimacies. Younger than management education, entrepreneurship education is nevertheless confronted with an additional challenge: building political legitimacy, as political actors expect entrepreneurship curricula to significantly contribute to economic growth and to the development of the "knowledge-based society" as ascribed by the Lisbon Agenda (2006).

This paper examines the case of a French business school entirely dedicated to entrepreneurship education, so as to highlight how the organization "reinvented" itself and managed its identity and multiple legitimacies during its first years of existence. A survey of EFMD (2008) identified sixteen major European business schools dedicated to entrepreneurship. Among them, the business school we researched may be analyzed as an "extreme case", as it is the only French higher institution completely committed to entrepreneurship education. As empirical inquiries investigating "a contemporary phenomenon within its real-life context" (Yin, 2003: 13), case studies may be particularly appropriate for analyzing the dynamics present within particular settings. According to Eisenhardt and Graebner (2007), the choice of a single case study may be appropriate when exploring new phenomena, on a longitudinal basis. In order to examine the business school's legitimation processes over a period of six years, from 2004 to 2010, we used various sources - the school's archives, curricula and syllabi, interviews with key actors, and participant 
observation. Our research highlights the tensions that a higher education organization entirely dedicated to entrepreneurship encounters when building academic, market and political legitimacies and explores their impact on quality assessment. This extreme case may be informative for other business schools in the field of entrepreneurship willing to reach academic, market and political legitimacies while at the same time trying to develop a coherent and stable global strategy in a competitive higher education environment.

We first investigate the specific issues entrepreneurship education organizations are facing when shaping their legitimacy. Then, we focus on the case study research design and methodology. The results section shed some light on the legitimation processes of the business school, and discusses their impact on the school's quality assurance management.

\section{LITTERATURE REVIEW}

\section{II.1. Building legitimacy in higher education}

Legitimacy has been depicted as a generalized perception that the actions of an individual or those of an organization are desirable and appropriate within the current system of social norms and values (Suchman, 1995). Organizational legitimacy, defined as "the acceptance of the organization by its environment", is crucial for organizational survival and success (Kostova and Zaheer, 1999: 64). Moreover, organizational emergence and development are analyzed as a progressive acquisition and transformation of internal and external legitimacies, through multiple discourse and action-driven legitimation processes (Tornikoski and Newbert, 2007; Golant and Sillince, 2007). From the standpoint of higher education organizations, legitimacy is the combined outcome of various legitimation processes whereby organizations try to increase congruence between their activities and socially defined standards, as well as market expectations (Anderson and Smith, 2007: 486488). 
Legitimation, characterized as "the process through which legitimacy is achieved" (Hybels, 1995) is a great challenge for higher education organizations that have to establish and maintain different and sometimes divergent legitimacy requirements from national and international stakeholders. Rindova, Pollock and Hayward (2006) emphasize that organizations build internal and external legitimacy with the intention of enhancing their influence on various stakeholders, attracting future clients and employees, and gaining financial and public support. However, when it comes to higher education organizations, legitimacy is more than just about acquiring notoriety and reputation on a highly competitive national and international market (Van Damme, 2001). Building legitimacy in higher education is also about conveying a quality message relative to pedagogical contents and processes, pedagogical methods and teams, in an attempt to improve both the organization's market position and its ability to have an impact on society, culture and educational policies.

\section{II.3. Academic, market and political legitimacies}

Different types of legitimacies may be identified according to the specific position that an academic discipline occupies in the general academic field, as defined by particular criteria, such as the discipline's centrality, maturity, expansion, etc. Legitimacy reflects a field's "institutional power" (Lyytinen and King, 2004: 223), its theoretical and methodological distinctiveness, its applicable research capabilities and perceived value. According to Binks and his colleagues (2006), business education needs to demonstrate a double legitimacy - academic and market legitimacy. Concerning academic legitimacy, national and international accreditation institutions focus on the consistence of pedagogical processes linking pedagogical contents and methods to faculty composition and organizational design (Van Damme, 2001). Concerning market legitimacy, enterprises and clusters focus on the conformity of the business schools' pedagogical content and skill 
development to the needs of the market and firms (Kipping and Nioche, 1997; Starkey and Tiratsoo, 2007). According to Lorange (2005), even though most universities and business schools all over the world strive to acquire these two kinds of legitimacy, market and academic, they still have some work to do in order to increase their mutual coherence and convergence, because academic and market legitimacies may sometimes require different quality criteria to be met, and different quality assessment procedures to be implemented.

Entrepreneurship education also has to build political legitimacy. Entrepreneurship is presently given strong impetus by both national and European political actors, with entrepreneurship curricula facing intense political pressures to demonstrate ability to produce short- and mid- term results, i.e. substantially increase the number of start-ups, create new employment opportunities, and contribute to the young enterprises' growth and internationalization. As one may notice, academic and market legitimacy rely mostly on process and content-based quality indicators, whereas political legitimacy is based on the educational system's short- and mid-term outputs, i.e. precisely those quality indicators most difficult to address by a higher education organization (Grant and Perren, 2002). Tensions and contradictions between academic, market and political legitimacies may thus become more apparent as entrepreneurship education strive to acquire all three of them at the same time.

\section{RESEARCH DESIGN AND METHODOLOGY}

\section{III.1. Research objectives}

The objectives of this research were three-fold: a) to develop a framework through which to examine the legitimation processes of entrepreneurship higher education organizations; this framework links legitimating strategies to specific quality assurance indicators in order to allow empirical analysis; b) to test the framework in an empirical setting - i.e. an "extreme case" - in order to validate its explanatory power; c) to emphasize the 
dynamics of identity building and legitimacy acquisition and the tensions among the three types of legitimacy as well as their particular quality assurance indicators.

To accomplish these objectives, we employed a three-stage approach. We first reviewed organizational and social sciences literature on legitimacy and legitimation, and elaborated a general framework of legitimation processes for entrepreneurship education organizations; then, we identified the potential quality assurance indicators that business schools strive to maximize in order to achieve overall legitimacy among their internal and external stakeholders (see Table 1). Second, we analyzed the case of a business school entirely dedicated to entrepreneurship from 2004 to 2010 to test and refine our framework. Third, we used the insights gained from this case study to illustrate the tensions and contradictions among quality assurance indicators that entrepreneurship education organizations may encounter when trying to achieve legitimacy.

\section{III.2. Case description}

As empirical inquiries investigating "a contemporary phenomenon within its real-life context" (Yin, 2003: 13), case studies are useful in exploring the dynamics present within particular settings. According to Eisenhardt and Graebner (2007), the choice of a single case study ("extreme case study") may be appropriate when one wants to explore new phenomena on a longitudinal basis.

Eight years ago, a higher education organization of the Paris Chamber of Commerce became a business school entirely dedicated to entrepreneurship, which is a unique position in the French higher education landscape. During six years, the business school carried out a profound transformation of its Bachelor and Master, launched new vocational learning programs for managers and entrepreneurs, a center of research in entrepreneurship, a club of entrepreneurs, a business angel's network, and a school incubator whereby novice 
entrepreneurs start up sixty to eighty new ventures every year. This repositioning had manifold implications in terms of legitimacy acquisition. The business school put into practice several strategies aiming to demonstrate the quality of its processes and outcomes so as to achieve academic, market and political legitimacies. In December 2008, the school became a member of the "Conférence des Grandes Ecoles", one of the most prestigious quality labels in French higher education.

\section{III.3. Data collection}

We used various sources of data in order to empirically test and refine our legitimation framework over a period of six years' field research, from 2004 to 2010 . We employed participant observation ${ }^{1}$ and semi-directed interviews, and we surveyed the business school's archival documentation and publications. We collected and analyzed official documents, which specify the business school's position, business plan and programs, faculty descriptions, web and press material. Paper and electronic documentation, including minutes of meetings and managers' memos, are related to the shaping of strategic choices and priorities and highlight many concurrent internal negotiations aiming to prioritize one form of legitimacy over another. The articulation of data extracted from participant observation, interviews and document analysis facilitated triangulation, which strengthened the internal validity of our case study (Eisenhardt, 1989; Yin, 1984). At the end of fieldwork, 50 semidirected interviews were conducted with the business school founder and the founding team (professors, researchers, and administrative staff); from the very beginning of the case study, the two authors engaged in complete participant observation, with over 300 daily staff meetings over a period of 6 years, which addressed strategic and operational issues.

\footnotetext{
${ }^{1}$ The authors were professionally involved with the business school : one of the authors was the Head of the Master program from 2005 to 2008, then the school's Director from 2008 to 2010; the other author was a Master and Bachelor professor from 2005 to 2008, then the Head of the Master program from 2008 to 2010.
} 


\section{III.4. Data analysis}

We analyzed the data using the legitimation framework and the quality assurance indicators shown in Table 1. We first coded and categorized verbal and written data according to three main categories - academic, market, and political legitimacies; second, we organized data within these three categories according to the specific quality assurance indicators of each form of legitimacy. We systematically recorded both temporal and contextual environments so as to record the chronological dimension of the overall legitimation process of the business school. Data interpretation is based on the idea that legitimation strategies may be conceptualized as "organizational goals" (Woodword, Edwards and Birkin, 1996). The formulation of organizational goals includes sharpening and clarifying present organizational purposes, adding new objectives or relinquishing old ones, shifting priorities among objectives, and altering the major mission of the organization.

In order to legitimate a heterogeneous organizational identity, the business school had to articulate the pursuit of its numerous and varied organizational goals as specific means or sub-goals of acquiring academic, market and political legitimacies (see Table 1). Mintzberg and Lampel (1999) identified four main configurations of strategic goal-striving within organizations: a) combination of existing goals in one unique global objective; b) systematic pursuit of existing goals treated as constraints to be meet at a minimum level of performance; c) maximization of one goal, while all the others are treated as constraints; d) consecutive maximization of existing goals, so as to meet them successively at their maximum level of performance. The longitudinal case study analysis provided a chronological reconstruction of the business school's strategic goal configuration in what concerns the achievement of legitimacy. 
The case study indicates that the business school successively strived to attain the three types of legitimacy throughout the first eight years after its foundation. The organization's strategic goal-striving may be thus be qualified as a "consecutive maximization of existing goals" in Mintzberg's and Lampel's (ibid.) terms, that is the consecutive achieving of academic, market and political legitimacies.

Table 1

FRAMEWORK OF LEGITIMACY FORMS AND QUALITY ASSURANCE INDICATORS IN ENTREPRENEURSHIP EDUCATION ORGANIZATIONS

\begin{tabular}{|c|c|c|c|c|c|}
\hline \begin{tabular}{|c|} 
FORMS OF \\
LEGITIMACY \\
(organizational macro-level)
\end{tabular} & DEFINITION & KEYWORD & STAKEHOLDERS & TYPE OF INDICATORS & $\begin{array}{l}\text { QUALITY ASSURANCE } \\
\text { INDICATORS } \\
\text { (organizational micro-level) }\end{array}$ \\
\hline $\begin{array}{l}\text { ACADEMIC } \\
\text { LEGITIMACY }\end{array}$ & $\begin{array}{l}\text { the level of } \\
\text { conformity to } \\
\text { social norms and } \\
\text { values, and to the } \\
\text { rules and } \\
\text { regulations of } \\
\text { authority } \\
\text { institutions }\end{array}$ & LEARNING & $\begin{array}{l}\text { national and } \\
\text { international } \\
\text { accreditation } \\
\text { institutions; } \\
\text { media; scholars }\end{array}$ & $\begin{array}{l}\text { process and content-based } \\
\text { quality indicators }\end{array}$ & $\begin{array}{l}\text { the consistence of pedagogical } \\
\text { processes linking pedagogical } \\
\text { content and methods to faculty } \\
\text { composition and } \\
\text { organizational design ; the } \\
\text { school's pedagogical and } \\
\text { research performance; the } \\
\text { quality and involvement of the } \\
\text { faculty in fulfilling the school's } \\
\text { mission }\end{array}$ \\
\hline MARKET LEGITIMACY & \begin{tabular}{|} 
the level of \\
conformity of \\
pedagogical \\
content and skill \\
development to the \\
needs of the \\
market and firms
\end{tabular} & WORKING & $\begin{array}{c}\text { national and } \\
\text { international firms; } \\
\text { professional } \\
\text { associations; } \\
\text { alumni; media }\end{array}$ & $\begin{array}{l}\text { process and content-based } \\
\text { quality indicators; short- } \\
\text { and mid-term output } \\
\text { indicators }\end{array}$ & $\begin{array}{l}\text { the quality of alumni } \\
\text { employment (economic } \\
\text { sectors, type and size of firms, } \\
\text { functions and responsibilities, } \\
\text { wages) ; national vs. } \\
\text { international jobs }\end{array}$ \\
\hline $\begin{array}{l}\text { POLITICAL } \\
\text { LEGITIMACY }\end{array}$ & $\begin{array}{c}\text { the level of } \\
\text { conformity to local } \\
\text { development } \\
\text { requirements in } \\
\text { terms of startups } \\
\text { and new jobs } \\
\text { creation, growth } \\
\text { and } \\
\text { internationalization }\end{array}$ & DEVELOPING & $\begin{array}{l}\text { regional, national } \\
\text { and European } \\
\text { political actors; } \\
\text { investment banks; } \\
\text { Business angels; } \\
\text { media }\end{array}$ & $\begin{array}{c}\text { short- and mid-term output } \\
\text { indicators }\end{array}$ & $\begin{array}{l}\text { the business school's economic } \\
\text { performance in terms of } \\
\text { business creation and } \\
\text { development; quantitative and } \\
\text { qualitative indicators for public } \\
\text { and private funding; reputation } \\
\text { and external recognition of } \\
\text { economic expertise (school's } \\
\text { involvement in regional, } \\
\text { national and European } \\
\text { entrepreneurship policy- } \\
\text { making) }\end{array}$ \\
\hline
\end{tabular}

\section{FINDINGS}

The business school's evolution from 2004 to 2010 indicates a strategy of consecutive maximization of existing goals. During this period, the business school moved through five 
main phases of legitimacy building; each of them lasted between 12 and 18 months and focused on a specific legitimacy achievement, while the two other forms of legitimacy that were not prioritized at that moment were treated as constraints (a strategic goal-striving configuration acknowledged by Minzberg and Lempel, ibid.). We present here the overall legitimation process of an educational organization committed to establishing entrepreneurship as a recognized field of higher education, research and professionalization. We will thus emphasize the complex process of organizational legitimation that first began with an organizational identity-ascription and lead to a long journey of legitimacy assertion and identity reconfiguration.

\section{IV.1. The founding years}

From 2004 to the mid-2006, the business school focused first on achieving political legitimacy, then on acquiring academic legitimacy. Paris Chamber of Commerce and Industry launched the business school as an educational organization fully dedicated to economic development, aiming to enhance entrepreneurial intentions in young students, encourage new firm creation, support high-growth companies, and contribute to the sustainability of young enterprises in the Paris area. Therefore, the initial organizational identity-ascription positioned the business school as an entrepreneurship higher education organization, which was a singular position in the French educational landscape at that time. The founding of the business school was in conformity with a broader political agenda. Following Commissioner Verheugen's 2002 and 2003 proposals to stimulate entrepreneurial initiatives in the EU and at the initiative of Minister Renaud Dutreil, the French Parliament voted several laws that significantly encouraged entrepreneurial activity and development. In order to support Dutreil's vision, the Paris Chamber of Commerce decided in December 2004 to reposition the business school, which for several decades had been a classical business school of middle 
management, as a business school dedicated to entrepreneurship. The new educational organization was meant to train a new generation of French opportunity-responsible and growth-motivated entrepreneurs. In order to produce political and academic legitimacies, the business school articulated a consistent stream of external communication claiming that the business school's purpose was to train entrepreneurs, trigger firms' creation, and develop entrepreneurial culture.

This political mission, recurrently stressed as one of the business school's key features, informed the academic profile of the business school. In 2005, the business school launched a Master's program in entrepreneurship and a school incubator. In 2006, the Bachelor's program was re-designed with an entrepreneurship-based curriculum. A new research center was established, with young professors specialized in entrepreneurship. These strategic operations indicate that from 2005 until the middle of 2006 the main legitimacy focus was on academic issues rather than political concerns. With the intention to concentrate more human and financial resources onto an original but expensive pedagogy, the business school progressively closed its older programs that were not directly connected to entrepreneurship and encouraged professors to develop new skills in entrepreneurship education. The school's ability to experiment with new pedagogical methods and tools was then significantly improved, as well as its teaching and research quality. In contrast with other business schools that had developed incubators without integrating them into their curricula, pedagogical managers were keen on facilitating the access of all students to the school's incubator, either for collective virtual start-up projects or for starting up their own businesses.

For the pedagogical and research teams, the challenge was to build and convey a distinctive educational model, a strong "pedagogy of entrepreneurship", as opposed to mainstream management education. Kyrö and Carrier (2005: 25) called for an "action-based pedagogy" in entrepreneurship, with more computerized and behavioural simulations, games, 
role-playing, films, experiential approaches, more original and unconventional teaching methods. Students enrolled in the business school's entrepreneurship curricula need to develop their ability to think critically and to revise existing stores of knowledge and abilities through knowledge production in "real life" situations (Binks, Starkey, and Mahon 2006: 15). Experiential learning modules were therefore implemented with the purpose of enabling students to act and think more autonomously and responsibly: "the main learning benefit of experiential methods is to enhance the students' ability to become actors of their own learning processes and, consequently, of their entrepreneurial behaviours", explained the Head of the Bachelor Program. Still, "experiential learning methods are a challenge for quality assessment in higher education, since the relationship between learning objectives and learning outcomes may be more difficult to evaluate because of the holistic approach of the pedagogical situation", observed the professor in charge of coordinating the AACSB accreditation process. Thus, the use of experiential methods may actually delay the organization's academic and market legitimization processes: as the business school's Director noticed, "our pedagogy may be difficult to evaluate through commonly shared management quality indicators, and thus the academic legitimacy of entrepreneurship curricula making extensive use of experiential methods may be ultimately endangered".

\section{IV.2. Striving to get market legitimacy}

In order to get more financial and human resources, the business school became in 2007 part of a holding together with another business school specialized in trade and international affairs, that had already been developing for fifteen years a Bachelor's and a Master's program entirely dedicated to commerce and negotiation. At that time, the business school we researched was still exploring and inventing its academic distinctiveness, but the main focus was on achieving market legitimacy. 
As the new Bachelor's and Master's programs were sending to the market their first alumni, the challenge was to demonstrate that former students were either entrepreneurs or business developers within SMEs and large corporations. Constant efforts were made to encourage students to start up their own business and become entrepreneurs within the school incubator: 20 new firms were created during the first year, 35 during the second, and 50 during the third. In order to support the growth of these young enterprises, a Club of entrepreneurs was created at the end 2005. In 2007, the incubator launched a post-incubation program, the "Business Angels' Tour", a specific training program where the best entrepreneurs had the opportunity to meet business angels and convince them to invest in their businesses. Thanks to the initial efforts put in building political legitimacy, regional financial actors were already involved in the business school's activities and were interested in investing time and money in the new firms' development. Moreover, later that year, the business school was invited to contribute to a national training program for business angels, the school's ability in training business investors for start-ups was thus acknowledged and its market legitimacy in terms of business creation received national recognition.

At the same time, the business school was preoccupied with evaluating students' employment as business developers. French firms were initially rather reluctant to hire "entrepreneurial profiles": HR managers of large companies feared that they may be too aggressive or too individualistic; business-owners at the head of SMEs feared that they may "steal" their good ideas and become future competitors. One of the school's objectives was to demonstrate that students-entrepreneurs were competitive future employees, therefore able to launch and develop innovative business projects. Regular meetings and events with corporate representatives were organized to jointly identify the best employment opportunities for students with an entrepreneurial academic background. As a result, at the end of $2007,95 \%$ of the Master's students were appropriately employed or created their own businesses within six 
months after graduation and $86 \%$ of the Bachelor's students were offered a choice of three internships at the end of their program. In $2008,25 \%$ of the firms involved in the business school's activities conveyed their interest in developing pedagogical projects in corporate entrepreneurship with Master's students. This is a good market recognition indicator, as only $10 \%$ of French firms are concerned with corporate entrepreneurship.

The organization and functioning of higher education programs specialized in management traditionally juxtaposed business schools and enterprises as the two faces of a binary system. Entrepreneurship curricula challenged this model and progressively replaced it with an educational paradigm whose intention is to systematically articulate business schools with enterprises and business incubators into an "open learning environment". Kyrö and Carrier (ibid.: 29) noticed that, in many cases, new university structures are needed for entrepreneurship education. These structures allow students to circulate within an entrepreneurial environment conceptualized as an "open environment" (ibid.). Ideally, entrepreneurship scholars imagine this "open environment" as a pedagogical setting where there would be no boundaries between the classroom and the surrounding reality, or between academic disciplines and economic actors. Learning in such an open environment could therefore consist in "increasing and supporting competences for enjoying and acting in complexity and insecurity and recognizing as well as creating opportunities involved in it" (ibid.: 28).

Business schools entirely dedicated to entrepreneurship are therefore not only in a partnership relation with various enterprises; these schools effectively and directly contribute to business creation and development. Consequently, they need to continuously optimize their pedagogical approaches and design specific pathways between their academic curricula and school incubators. However, in terms of academic legitimacy, the business school "was facing a strong dilemma when we were asked to explain the role of the school's incubator" stressed 
the Director of the incubator. An incubator coach noticed that "national and international accreditation institutions do not take into account the school incubators' pedagogical contribution because they do not deliver degrees, even though they can deliver credits". Several French business schools, rather than developing their own incubator, therefore preferred to work in partnership with already existing private and public incubators.

\section{IV.3. Amongst the best French academic institutions}

From 2008 to 2009, the business school strived to reinforce its academic legitimacy: teaching quality and curricula consistency became major issues in the attempt to enhance the school's attractiveness and consolidate its notoriety among the other 200 French business schools. At the national level, the business school struggled to reach the "Conférence des Grandes Ecoles" label, which recognizes the academic excellence of 40 French business schools. In order to get this national accreditation, the Master's program was re-designed to develop three profiles that pointed out the evolution of the school's identity - entrepreneurs, business developers, business support and consulting specialists. Eager to defend an interdisciplinary approach of entrepreneurship, the research team considerably contributed to the school's academic legitimacy. At the end of 2008, the business school received the "Grande Ecole" accreditation. The school's success in training entrepreneurs, business developers, and entrepreneurial consulting specialists was therefore acknowledged, as well as its research capacity in building a robust interdisciplinary approach to entrepreneurship. At that moment, the business school's educational model acquired national academic legitimacy. Immediately afterwards, the school decided to face an additional challenge in order to boost its international academic recognition: the business school officially entered the AACSB accreditation process at the beginning of 2010 . 
Pretorius et al. (2005) argue that entrepreneurship education challenged the functioning of traditional management programs' pedagogical teams, who classically distinguished between academics and business experts. Entrepreneurship pedagogical teams introduce a new role, that of the "facilitator" standing at the core of the entrepreneurial educational system. Ideally, a good facilitator should increase the students' motivation and entrepreneurial intentions, as well as develop the students' entrepreneurial and business skills according to market, social and cultural requirements. In reality, the facilitator's role is often achieved not by a sole isolated individual but rather by an entire group of academics, business professionals and coaches. "We noticed a progressive and profound hybridization of the original profiles, with professors becoming entrepreneurs, business professionals becoming professors, and the head of the entrepreneurs' club preparing a thesis in entrepreneurship", stressed the school Director. From an academic standpoint, "it is obvious that the legitimacy of this kind of heterogeneous entrepreneurial pedagogical teams may sound dubious: their various expertises and their status flexibility could be beneficial for the students' skill acquisition, but they may also puzzle the quality standards of accreditation institutions", observed the professor in charge of the AACSB accreditation process.

\section{IV.4. Consolidating political legitimacy}

From 2009 to 2010, the business school put great efforts in achieving international recognition, mainly through consolidating political legitimacy at the European level. A close examination of international academic partners indicated that, over the past 20 years, the school had developed numerous and various partnerships with academic institutions. However, very few of them were genuinely interested in entrepreneurship. After visiting several potential and actual partners in Northern and Eastern Europe as well as Northern Africa, the business school issued the hypothesis that universities were not the best allies in 
helping French students and professors to understand the development of young firms abroad. Local business networks, business associations, entrepreneurial think tanks, and foreign agencies for innovation and development were identified as more appropriate future partners. As a consequence, the business school organized international meetings so as to attract the right partners for new international pedagogical projects.

In 2006, the business school launched a national conference on women entrepreneurs that became an international research seminar in 2007 and 2008. In 2008, Glamorgan University (UK) invited the business school to join the first European project on women entrepreneurs (WEEU). In 2008 and 2009, the business school organized an international conference for French and American entrepreneurs. In 2010, the Danish representation office in Brussels commissioned the business school to design an original mapping method of EU's sensitization activities to entrepreneurship along with other eleven European partners, the majority of which belonged to European political networks. In the same year, the French Ministries of Economy and Higher Education designated the business school as the leader of one of the twenty French "poles of excellence for student entrepreneurship", which was a major political recognition of the school's ability to integrate academic, business and institutional partners to boost entrepreneurship (see Figure 1).

\section{FIGURE 1}

BUILDING LEGITIMACY: A CHRONOLOGICAL RECONSTRUCTION 


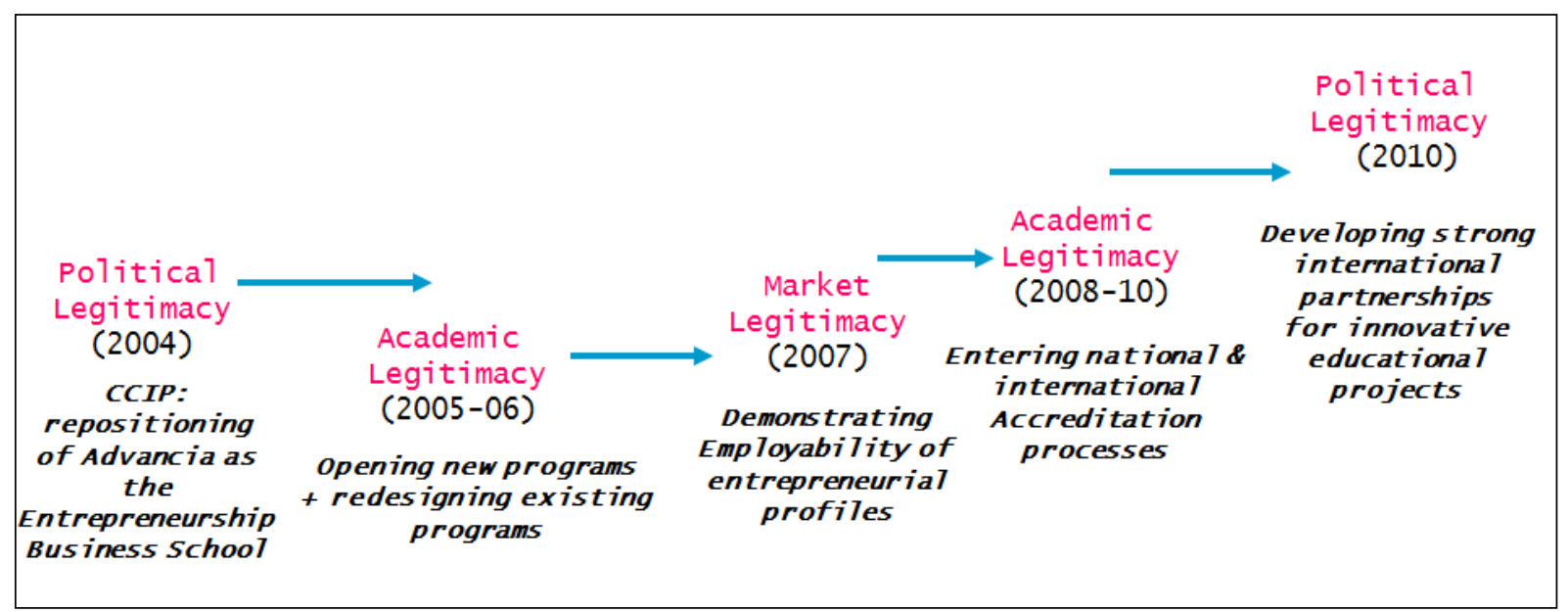

\section{DISCUSSION}

In this extreme case, entrepreneurship education strives to simultaneously achieve academic, market and political legitimacies. Sometimes, as we have seen, the three processes of legitimation happen to be convergent, while other times they may become rather divergent and thus be the source of strong tensions within entrepreneurship curricula and higher education organizations. Even though the business school achieved growing legitimacy from 2004 to 2010, the strategic decision to consecutively maximize one type of legitimacy at a time, while treating the other two as constraints, has an impact on the various Quality Assurance Indicators (QAI) to be implemented and regularly evaluated in the attempt to get external recognition. When concurrently working on quality assurance indicators, there is a risk of conveying the same information to academic, market and political stakeholders, that is, to convey counter-productive information about irrelevant quality assurance indicators, instead of focusing solely on the quality assurance indicators that are separately relevant to academic, marketing or political legitimacy. At the same time, working in concert on the three main categories of quality assurance indicators may bring about cognitive and organizational difficulties for staff and professors. This process required a great amount of flexibility from 
the business school's management and a great ability in building an appropriate communication strategy.

Concretely, in spite of their clear convergence, we observed frequent divergences among the staff, especially between those respectively dedicated to market and academic legitimacies, or between those respectively involved in developing academic and political legitimacies. We also identified some overlapping activities in achieving the three legitimacies, as follows: the students' selection and follow-up, the vaporization of the faculty's intellectual output, the quest for entrepreneurial innovative pedagogical methods, and the integration of four different educational communities around the topic of entrepreneurship - the incubator's community of entrepreneurs and coaches, the network of experts supported by the sensitization programs, and the research and faculty communities. However, conflicts arose in relation to the human and financial resources to be mobilized in pursuit of the three types of legitimacy. For instance, the development of entrepreneurship relied on political legitimacy, that is, on the ability to obtain public support and funding, whereas corporate entrepreneurship development relied on market legitimacy, that is, on the ability to attract corporate funds and partnerships. Another area of disagreement was the designing of programs targeting specific entrepreneurial populations (such as women, immigrants or young entrepreneurs) and industries: for those focusing on political legitimacy, these programs were valuable, whereas those committed to developing market legitimacy feared that a niche strategy would cut off the school from other potential clients and economic partners. These organizational contradictions and paradoxes when attempting to articulate the three types of legitimacy-acquisition had a powerful impact on the evolution of pedagogical contents, methods and teams and the overall school organization.

\section{CONCLUSION}


Throughout the last twenty years, in developed countries, governments and business schools put forward the expansion of entrepreneurship education in order to enhance the number of start-ups, emphasized as key players of innovation and economic growth. Many entrepreneurial programs and organizations therefore emerged to sustain this political, economic and cultural agenda, such as educational programs, business incubators and nurseries, entrepreneurial clubs and networks. In this context, entrepreneurial education deals with several issues that are not exclusively academic in nature. Of course, curriculum development, along with the constitution of appropriate pedagogical teams and effective student recruitment are at the core of entrepreneurship higher education. In addition, entrepreneurial programs and business schools also deal with market expectations and requirements in terms of skills acquisition. In other words, these programs and organizations need to ensure that those graduates who are not ready to start their own business after graduation will still be able to find appropriate positions in already existing companies, as managers or consultants. This extreme case indicates that entrepreneurship education sometimes requires an organizational strategic reconfiguration and, thus, the implementation of a set of consistent processes to manage organizational identity change over time as it attempts to gain academic, market and political legitimacies.

This case also illustrates the various tensions and contradictions facing a higher institution dedicated to entrepreneurship when trying to achieve academic, market and political legitimacy. In this context, acquiring academic legitimacy is about challenging the field of management and its capacity to welcome a new discipline, i.e. new pedagogical contents, methods, faculty, and organization, and to elaborate new quality objectives and indicators. The business schools' efforts to acquire academic legitimacy are not exclusive, as the business school was also involved in two complementary processes targeting market and political legitimacies. Tensions are expected since the three legitimizing processes have 
distinct aims: the accreditation institutions, when it comes to academic legitimacy: public and private organizations and firms, when it comes to market legitimacy; and the French government and EU institutions, when it comes to political legitimacy.

Several authors have already emphasized the importance of acquiring market and political legitimacies for higher education curricula (Starkey and Tiratsoo, 2007; Lorange, 2008). However, little is known about the way in which entrepreneurship education may rearticulate these three types of legitimacy that management education frequently presents as uniquely stemming out of the market of higher education. For instance, this case indicates that a school does not always comply with market requirements when it acts in accordance with political requirements. Conversely, it also indicates that academic and political legitimacies may clash when trying to use the same quality assessment criteria. In order to equally and simultaneously respond to these three legitimizing processes, entrepreneurship education may need to further challenge major educational categories, such as the notions of "pedagogical contents", "methods", and "teams", as well as the educational environment and organizations.

\section{Bibliography}

Alberti, F. (1999). Entrepreneurship Education: Scope and Theory, Entrepreneurial Knowledge and Learning. Conceptual Advances and Directions for Future Research, 6: 6484.

Aldrich, H.E. and Fiol, C.M. (1994). Fools Rush in? The Institutional Context of Industry Creation. Academy of Management Review, 19(4): 645-670.

Anderson, A.R. and Smith, R. (2007). The moral space in entrepreneurship: an exploration of ethical imperatives and the moral legitimacy of being enterprising. Entrepreneurship and Regional Development, 19(6): 479-497. 
Barnett, R. (1994). The Limits of Competence. Buckingham: Society for Research into Higher Education. London: Open University Press Buckingham, UK.

Binks, M., Starkey, K. and Mahon, C. (2006). Entrepreneurship Education and the Business School. Technology Analysis \& Strategic Management, 18(1): 1-18.

Brewer, M.B. (1991). The social self: On being the same and different at the same time. Personality and Social Psychology Bulletin, 17: 475-482.

Bunnell, T. (2007). The international education industry. An introductory framework for conceptualizing the potential scale of an alliance. Journal of Research in International Education, 6(3): 349-367.

Crosby, P. (1984). Quality Without Tears. New York, NY: McGraw-Hill.

Gartner, W.B. and Vesper, K.H. (1994). Experiments in Entrepreneurship Education: Successes and Failure. Journal of Business Venturing, 9(3): 179-187.

Gilbert, D. (2010). Integrating theory and practice for student entrepreneurs: an applied learning model. Journal of Enterprising Culture, 18(1): 83-106.

Glynn, M.A. and Marquis, C. (2004). When Good Names Go Bad: Symbolic Illegitimacy in Organizations. Research in the Sociology of Organizations, 2: 147-170.

Golant, B.D. and Sillince, J.A.A. (2007). The constitution of organizational legitimacy: a narrative perspective. Organization Studies, 28(8): 1149-1167.

Grant, P. and L. Perren (2002). Small Business and Entrepreneurial Research, Meta-Theories, Paradigms and Prejudice. International Small Business Journal, 20(2): 185-211.

Eisenhardt, K.M. and Graebner, M.E. (2007). Theory building from cases: opportunities and challenges. Academy of Management Journal, 50(1): 25-32.

Hjorth, D. and Steyaert, C. (2003). Entrepreneurship beyond (a new) economy: creative swarms and pathological zones, in Chris Steyaert and Daniel Hjorth (eds.), New Movements in Entrepreneurship (286-303), Cheltenham: Edward Elgar. 
Honig, B. (2004). Entrepreneurship Education: Toward a Model of Contingency-Based Planning. Academy of Management Learning \& Education, 3(3): 258-273.

Hybels, R.C. (1995). On Legitimacy, Legitimation, and Organizations: A Critical Review and Integrative Theoretical Model. Academy of Management Journal proceedings, 241-245.

Jaspers, K. (1946). Die Idee der Universität. Berlin/Heidelberg: Springer Verlag.

Katz, J. (2008). Fully Mature but Not Fully Legitimate: A Different Perspective on the State of Entrepreneurship Education. Journal of Small Business Management, 46(4): 550-566.

King, B.G. and Whetten, D.A. (2008). Rethinking the relationship between reputation and legitimacy: A social actor conceptualization. Corporate Reputation Review, 11(3): 192-207. Kipping, M. and Nioche, J.-P. (1997). Politique de productivité et formation à la gestion en France (1945-1960). Entreprises et Histoire, 5.

Kostova, T. and Zaheer, S. (1999). Organizational legitimacy under conditions of complexity: the case of the multinational enterprise. Academy of Management Review, 24(1): 64-81.

Kuratko, D.F. (2005). The Emergence of Entrepreneurship Education: Development, Trends, and Challenges. Entrepreneurship Theory and Practice, 29(5): 577-598.

Kyrö, P. and Carrier, C. (Eds.) (2005). The Dynamics of Learning Entrepreneurship in a Cross-Cultural University Context. Hämeenlinna, FI: University of Tampere, Research Centre for Vocational and Professional Education.

Leitch, C.M. and R.T. Harrison (1999). A process model for entrepreneurship education and development. International Journal of Entrepreneurial Behavior and Research, 5(3): 83- 109. Lorange, P. (2005). Strategy means choice: also for today's business schools! Journal of Management Development, 24(9): 783-790.

Lyytinen, K. and King, J.L. (2004). Nothing at the center? Academic Legitimacy in the information systems field, Journal of the Association for information systems, 5(6): 220-246. 
Milliken, J. and Colohan, G. (2004). Quality or Control? Management in Higher Education. Journal of Higher Education Policy and Management, 26(3): 381-391.

Mintzberg, H. and Lampel, J. (1999). Reflecting on the Strategy Process. Sloan Management Review, 40(3): 21-30.

Mukherjee, S.P. (1995). Quality assurance in an education system. Total quality management \& business excellence, $6(5): 571-578$.

Petridou, E. and Sarri, K. (2011). Developing "potential entrepreneurs" in higher education institutes. Journal of Enterprising Culture, 19(1): 79-99.

Pretorius, M., Nieman, G. and J. Van. Vuuren (2005). Critical Evaluation of Two Models for Entrepreneurial Education. International Journal of Education Management, 19(5): 413-427.

Rae, D. (2006). Entrepreneurial Learning: A Conceptual Framework for Technology-Based Enterprise. Technology Analysis \& Strategic Management, 18(1): 39-56.

Rao, M.V.H. (1994). The Social Construction of Reputation: Certification Contests, Legitimation, And The Survival of Organizations in the American Automobile Industry: 1895-1912. Strategic Management Journal, 15: 29-44.

Rindova, V.P., Pollock, T.G. and Hayward, M.L.A. (2006). Celebrity firms: The social construction of market popularity. Academy of Management Review, 31(1): 50-71.

Rindova, V. and Fombrun, C. (1999). Constructing competitive advantage: The role of firmconstituent interactions. Strategic Management Journal, 20: 691-710.

Selznick, P. (1957). Leadership in administration, New York, NY: Harper \& Row.

Starkey, K. and Tiratsoo, N. (2007). The Business School and the Bottom Line. Cambridge, UK : Cambridge University Press.

Steyaert, C. and Hjorth, D. (2007). Entrepreneurship as social change. Cheltenham, UK: E. Elgar. 
Suchman, M.C. (1995). Managing legitimacy: strategic and institutional approaches. Academy of Management Review, 20(3): 571-610.

Tornikoski, E.T. and Newbert, S.L. (2007). Exploring the determinants of organizational emergence: A legitimacy perspective. Journal of Business Venturing, 22(2): 311-335.

Van Damme, D. (2001). Quality Issues in the Internationalization of Higher Education. Higher Education, 41: 415-441.

Weber, M. (1964). L'éthique protestante et l'esprit du capitalisme. Paris: Librairie Plon.

Widrich, S.M., Erhan, M. and Grant, D. (2002). Measuring the dimensions of quality in higher education's, Measuring the dimensions of quality, 13(1): 123-131.

Woodword, D.G., Edwards, P. and Birkin, F. (1996). Organizational legitimacy and stakeholder information provision. British Journal of Management, 7: 329-347.

Yin, R.K. (2003). Case study research, design and methods. Newbury Park, UK: .Sage Publications. 